JULIJANA KRAJNC, M.Sc.

E-mail: julija.krajnc@aero.si

AERO, Chemical, Graphic and Paper Manufacturers, d.d.

Ipavčeva 32, 3000 Celje, Slovenia

KLAVDIJ LOGOŽAR, Ph.D.

E-mail: klavdij.logozar@uni-mb.si

BOJANA KOROŠEC, Ph.D.

E-mail: bojana.korosec@uni-mb.si

University of Maribor, Faculty of Business and Economics

Razlagova 20, 2000 Maribor, Slovenia
Traffic Management

Preliminary Communication

Accepted: Oct. 29, 2010

Approved: Dec. 20, 2011

\title{
ACTIVITY-BASED MANAGEMENT OF LOGISTIC COSTS IN A MANUFACTURING COMPANY: A Case of Increased Visibility of Logistic Costs in a Slovenian Paper Manufacturing Company
}

\begin{abstract}
Both the transparent reporting of logistics costs and the related accounting of their cost drivers present a significant factor for the successful management of material flows and the related logistics activities in production companies. These costs, which are mainly reported as part of overhead (indirect) costs in such companies, usually remain hidden or are not explicitly visible when the traditional method of accounting is applied. The aim of this research is to create a model of activity-based accounting of logistics costs in a production company, and to test its efficiency in the disclosure of logistics costs compared with traditional cost accounting. The application of the model in a production company shows that an activity-based approach discloses as much as $108 \%$ more logistics costs at the level of a group of products than the traditional cost-accounting approach. Further, detailed information on logistics costs obtained in this way enables their more efficient management.
\end{abstract}

\section{KEY WORDS}

logistic costs, activity-based costing, cost allocation, cost visibility, cost management

\section{INTRODUCTION}

In recent decades, the conditions in the world of business have changed considerably, due to globalisation and the resulting elimination of barriers among different national economies. This has been prompted by significant technological changes, principally in transport, communications, and electronic data handling. Today, companies face more and more intense competition which forces them to adapt to the specific demands of their customers primarily by product di- versification and differentiation, flexible delivery dates, and a wide range of distribution channels - as well as by providing special customer services. Due to this development, the need for efficient and effective material flows and their costs management is increasing. "Logistics is becoming more and more recognized as the critical step in the process of meeting the demands of the customer." [1]. Moreover, with regard to the importance of customer service in a company's strategy, companies have a growing need to concentrate on logistics costs [2]. As a result of development trends, the scope of these costs has been on the increase [3]. In addition, the proportion of overhead costs $[4,5]$ including logistic costs, which are by their nature seen mainly as indirect costs, is also rising [2].

Transparent reporting of logistics costs and the related accounting of their cost drivers present a significant factor for the successful management of material flows and the related logistics activities in production companies.

The traditional cost accounting system in manufacturing companies does not assure the transparency of logistics costs because the indirect part of these costs remains a more or less poorly visible element of overhead costs, both in terms of non-manufacturing costs (i.e. sales, general and administrative expenses) and manufacturing costs. These indirect costs are then either all pooled at the level of the company and further allocated to products, or first allocated to a few departments and then to products, with the use of direct labour hours or machine hours as typical arbitrary allocation bases [6].

In addition, the arbitrary allocation of indirect costs to products using (their) volume-related allocation 
rates does not enable such a system to adequately show these costs in either their total amount nor at the level of individual products, customers, or other cost objects. For that reason the traditional product-costing system has been criticised in logistics-related literature for a number of years [2, 4, 1, 3]. Furthermore, it has provided a basis for several justified initiatives concerning the activity-based management of logistics costs according to the principles of activity-based costing - the $A B C$.

The ABC method is based on a two-level system of establishing and allocating indirect costs. It is founded on the premise that costs are incurred by the use and the availability of resources needed in the implementation of the activities performed for the needs of various cost objects. Therefore, costs of resources are first linked to activities incurring those indirect costs, and then the activities are linked, with the use of measurable activity cost drivers, to cost objects (e.g. customers, products, channels) [5]. This guarantees both the transparency of indirect costs per activities incurring these costs, and more realistic information on costs per individual cost object than is the case with traditional cost accounting. The latter is particularly true when a proportion of indirect costs is high, and when the resources for cost objects are used in disproportionate amounts [5]. . $^{1}$

Considering the increasing scope and the variety of logistics processes, it is understandable that the ABC method has been researched in relation to logistics. A number of theoretical analyses show the potential benefits of applying the ABC method in logistics. For example, Pohlen and LaLonde [2] justify the possibility of applying the ABC method in logistics in order to assure better visibility of logistics costs in organisations, to improve the establishment of product costs, to measure the achievements of logistics in organisations, and to expand its application to the entire supply chain. The applicability of the method to establish 'real' product costs is also justified by Pirttilä and Hautaniemi [7]. They claim that the benefits of its use compared with traditional methods are greater if there are differences between the products in product values (weight, size, volume, fragility), customer type (small, large), market areas (geographic distance, transportation possibilities), and product handling or distributions channels. Stapleton et al., [1] justify a potential usefulness of the $A B C$ method application in the evaluation of logistics services profitability, while Goldsby and Closs [8] focus on its benefits for an improved allocation of resources within a supply chain and logistics reengineering processes. The literature also provides theoretical discussions about the usefulness of the $A B C$ method in comparison to other support tools for strategic management; for example, Liberatore and Miller [9] justify it in relation to the balanced scorecard, or BSC. According to Baykasoğlu and Kaplanoğlu [10], Rotch analysed the possibilities for the introduction of $A B C$ in logistics in comparison to production and claims that "output is harder to define, data collection and measurements are more complicated than in manufacturing, activity in response to service requests may be less predictable, joint capacity represents a high portion of total costs and is difficult to link to output related activities."

The application of the scope and level of ABC in logistic companies has also been discussed. For instance, Innes et al., [11] established that among the UK's largest companies, financial organisations exhibit the highest adoption rates of $A B C$ (more than $40 \%$ of such organisations have adopted $A B C$ ), while manufacturing organisations adopt it to a far lesser degree (14\%). Other companies, including logistics ones, use ABC even less (12\%). Similarly, Pirttilä in Hautaniemi [7] established a lower use of ABC in the Finnish logistics companies in comparison to manufacturing companies. A relatively low level of the use of the ABC method in logistics companies, mainly for an occasional updating of information on costs and costs analysis, have been confirmed by the research of Pohlen and LaLonde [2] as well as Stapleton et al. [1].

However, the literature does not often report on individual cases of ABC use in logistics. Namely, in 2004 Stapleton et al., [1] established that the "application of ABC systems in logistics was still in its early stages." In 2008, Baykasoğlu and Kaplanoğlu [10] claimed that "the number of studies that present real life application of $A B C$, especially in logistics was very few." Not only are there just a few cases of ABC adoption in logistics companies (i.e. Themido et al. [4], Varila et al. [12], Baykasoğlu and Kaplanoğlu [10], Decker and Van Goor [13], Goldsby and Closs [8], and Nurminen et al., [14]), but the evidence of the studies concerning the cases of the $A B C$ use in individual manufacturing organizations in the context of logistics management seems to be even scarcer. The study by Pirtillä and Hautaniemi [7] concerns the use of ABC only for the distribution logistics/warehouse of a manufacturing company, with capital costs of space and equipment calculated from the replacement costs by calculating the annuities for the resource lifetime. As well, the research from Wang et al., [3] presents the implementation of $A B C$ for logistics cost management in a Chinese consumer food product firm, observing internal logistics process split into the following seven sequential activities: customer order processing, warehousing, raw material purchasing, inspecting, processing and assembling, product loading, and delivering.

The survey of the literature dealing with $A B C$ in relation to the treatment of logistics costs leads to the conclusion that the problem of inadequate visibility of logistics costs in traditional cost accounting has received adequate theoretical treatment. For example, according to Stapleton et al., [1], "managers do not 
have adequate visibility for control over their costs" when the traditional cost-accounting model is applied. Nevertheless, neither the evidence of the research that would show, both explicitly and quantitatively, better efficiency of logistics costs reporting by the application of the $\mathrm{ABC}$ approach in manufacturing companies, nor the cases that would analyse all logistic subsystems in production companies in great detail could be found. The visibility of logistics costs must be as good as possible, and is one of the fundamental prerequisites for the exploitation of other theoretical benefits of applying the $A B C$ method in logistics. The quantification and the awareness of the extent of the problem of undisclosed logistics costs when the traditional accounting systems are applied compared to the use of the ABC approach can add substantially to the solution of this issue. In view of these facts, the purpose of this research is to form a model of activity-based accounting of logistics costs in a manufacturing company, and to test its efficiency for the disclosure of logistics costs compared to the traditional cost accounting in a given company.

The following part of the paper first presents briefly the key characteristics of the ABC model developed by the authors for logistics costs accounting in a manufacturing company. Second, the methods and the main results of its application in a selected manufacturing company are presented. The aim of the research was to test the validity of the following core hypothesis:

The developed model of activity-based monitoring of logistics costs in a manufacturing company discloses a significantly larger amount of logistics costs compared to the traditional cost-accounting model, and also presents them in a clearer form to facilitate their management.

\section{DESIGN OF ACTIVITY-BASED MODEL FOR LOGISTIC COSTS ACCOUNTING IN A MANUFACTURING COMPANY}

The model for activity-based accounting of logistics costs designed by the authors of this paper divides logistics activity into four subsystems [15], i.e. purchasing logistics, internal (production) logistics, sales logistics and after-sales logistics. Within each subsystem, it further distinguishes between partial processes which need to be defined from the qualitative aspect considering their impact on the value added for the external buyers (i.e. a process does not have any impact, it has a direct impact, or it has an indirect impact). In addition, a distinction between scope-dependent processes and one scope-independent process is made at the level of each logistics subsystem. The scopedependent processes are basically those for which it can be concluded that the use or the engagement of their resources depends on measurable cost drivers.
The scope-independent process concerns each logistics subsystem's management (in its narrow sense) for which it is presumed that such dependence cannot be found. Nevertheless, the costs of these management processes should first be reported separately in order to measure their cost efficiency and to manage them. However, for the purpose of making strategic decisions about the profitability of products, these costs should be transferred to the dependent partial processes and should be further transferred to products via the cost drivers used, implemented, or guaranteed for the needs of individual products. Since the proportion of these management costs is assumed to be relatively small, they are allocated in the model to the partial processes of an individual logistics subsystem based on the costs defined at the level of dependent processes prior to this transfer. Thus, the proportionality of assuring the potentials of each subsystem's managing resources with the direct use of resources in its scopedependent processes is assumed.

Considering the defined manner of allocating the costs of independent processes of management to the dependent processes of individual logistics subsystems, the calculation of total costs of individual scope (volume)-dependent process in an individual logistics subsystems i (i.e. by adding a part of the allocated costs of this subsystem's management) can be expressed as follows:

$C d_{i j}=C d n_{i j}+\left(C d n_{i j}: \sum_{j=1}^{p_{i}} C d n_{i j}\right) \times C i_{i}$,

where:

$C d_{i j}$ - total costs of the $j^{\text {th }}$ scope-dependent process of the $i^{\text {th }}$ logistics subsystem (including a part of the allocated costs of the $i^{\text {th }}$ subsystem's management),

$C d n_{i j}$ - net costs of the $j^{\text {th }}$ scope-dependent process of the $i^{\text {th }}$ logistics subsystem (without the allocated costs of the $i^{\text {th }}$ subsystem's management),

$\mathrm{Ci}_{i}$ - total scope-independent costs (of management) of the $i^{\text {th }}$ logistics subsystem, and

$p_{i}$ - number of scope-dependent processes in a logistics subsystem $i$.

Furthermore, the establishment of costs per cost driver unit in an individual scope-dependent logistics process can be defined as follows:

$c d_{i j}=C d_{i j}: Q_{i j}$,

where:

$c d_{i j}$ - costs per unit of a cost driver of the $j^{\text {th }}$ scope-dependent process of the $i^{\text {th }}$ logistics subsystem,

$C d_{i j}$ - total costs of the $j^{\text {th }}$ scope-dependent process of the $i^{\text {th }}$ logistics subsystem (including a part of the allocated costs of the $i^{\text {th }}$ subsystem's management), 
$Q_{i j}-$ total quantity of cost drivers of the $j^{\text {th }}$ scopedependent process of the $i^{\text {th }}$ logistics subsystem, and

$i=1, \ldots$ to 4 , i.e. number of logistics subsystem observed (purchasing, internal, sales, and after-sales logistics).

After the costs per unit of a cost driver in a scopedependent process of a logistics subsystem are calculated, the total costs of this process needed for an individual product $(x)$ can be expressed as the following product:

$C d_{i j x}=c d_{i j} \times Q_{i j x}$,

where:

$C d_{i j x}$ - costs of the $j^{\text {th }}$ scope-dependent process of the $i^{\text {th }}$ logistic subsystem for product $x$, and

$Q_{i j x}$ - quantity of cost drivers of the $j^{\text {th }}$ scope-dependent process of the $i^{\text {th }}$ logistic subsystem for product $x$.

Indirect costs of all processes of a logistic subsystem $i$ for an individual product can thus be expressed by the following sum:

$$
\sum_{j=1}^{p_{i}} C d_{i j x}
$$

Total indirect logistics costs of all the four logistics subsystems for an individual product can be expressed by the following sum:

$$
\sum_{i=1}^{4} \sum_{j=1}^{p_{i}} C d_{i j x}
$$

Such a model of activity-based accounting of logistics costs enables the calculation of individual product costs, which clearly discloses the logistics costs at the level of each identified scope-dependent logistics process in each of the four logistics subsystems. According to the information needs, such logistics costs can then be aggregated at the level of the four logistics subsystems or some of their sub-processes.

\section{TESTING THE ABC MODEL EFFICIENCY FOR AN IMPROVED DISCLOSURE OF LOGISTIC COSTS - APPLICATION OF MODEL IN A SLOVENIAN PAPER MANUFACTURING COMPANY}

In order to test the hypothesis on the efficiency of the activity-based cost accounting model, we utilized the model in a paper manufacturing company. ${ }^{2}$ The execution of the application was based on an ABC introduction project model [16]. Its methodological concept was based primarily on Koletnik [17], while the initiation stage of the process implementation was founded on the approach defined by Turney [18] .

The production programme of the company comprises the following main groups of products: reposi- tionable products, self-adhesive tapes, self-adhesive materials for label industry, promotional products, and receipt paper rolls, as well as thermal rolls.

A part of logistics is organised within the production-technical division in a separate cost centre 'warehousing.' Other logistics processes are executed alongside other activities within other cost centres in the company's commercial and production-technical divisions. In addition, the quality control service, which is centrally organised as a professional service, is partly included in carrying out of these activities as well.

The existing accounting of logistic costs in the company is based merely on traditional methods, i.e. on the recording of different types of costs according to types of inputs (costs of materials, labour costs, depreciation costs, and costs of services), cost centres and cost objects. The logistics costs are recorded separately only to a certain degree. At the level of cost centres some logistics costs are recorded under a separate cost centre 'warehousing,' combining both the raw materials and the finished products warehouses of all production programmes, which decreases the accuracy of assigning these costs to cost objects. That is, these costs are first allocated (based on the number of receipts and shipments) to various production programmes and then, based on direct material costs based rate, applied to cost objects (products). Taking into account the heterogeneity of production (i.e. the diversity of products) and the heterogeneity of sales (i.e. the number of markets and a large number of buyers), such an accounting of logistics costs is inadequate, and may lead to bad business decisions. The costs of all other logistics processes are pooled together with all other indirect costs and are not accounted separately.

The next subject under analysis is the business segment "self-adhesive laminates/labels" and its logistics costs. The segment product range consists of:

- uncoated papers - universal label paper for general use, labels suitable for thermal transfer printing and special use,

- gloss-coated papers - used for the production of multicolour labels,

- data - for use in laser printers, copiers and inkjet printers,

- thermal papers - labels for supermarkets, shipments and bar-codes,

- specials - for high quality product labelling and advertising, and

- siliconized paper.

From the company's accounting information system, it was possible to extract the following data. The amount of total logistics costs for the analysed business segment for the time period January 2009 - August 2009 was EUR 138,696, which is $4.82 \%$ of all the costs (i.e. primary and secondary/allocated costs) recorded at this level of the company. Table 1 presents 
Table 1 - Logistic costs for the production of self-adhesive laminates according to the existing traditional method of cost recording for the time period January 2009 - August 2009

\begin{tabular}{||l|c||}
\hline \multicolumn{1}{|c|}{ Types of logistics costs for production “Self-adhesive laminates” } & Amount (EUR) \\
\hline \hline 1. Direct purchasing costs & 25,521 \\
\hline 2. Direct packaging costs & 41,892 \\
\hline 3. Costs of transport services & 51,002 \\
\hline 4. Costs of mail and postal packages & 137 \\
\hline 5. Current maintenance of means of transport & 1,219 \\
\hline 6. Costs of elimination of waste & 11,569 \\
\hline 7. Allocated costs from ‘Cost centre Warehouse’ & 7,356 \\
\hline \hline TOTAL logistics costs for business segment “Self-adhesive laminates” & 138,696 \\
\hline \hline Total costs for business segment “Self-adhesive laminates” & $2,875,847$ \\
\hline Proportion of logistic costs - as \% of total costs of the business segment & 4.8228 \\
\hline
\end{tabular}

Source: The authors' own research, based on the company's data

the types of these costs for the observed business segment in the company ${ }^{3}$.

In order to enhance the transparency of logistics costs, the model of activity-based accounting of logistics costs was tested for the same time period. To obtain and collect the data, the existing company documentation was analysed (i.e. the descriptions of jobs, the organisation structure, work orders and instructions, chart flows, annual reports, and other reports) and the work processes were observed (e.g. measuring the working time spent on individual processes).
In addition, the managers of the researched business segments were interviewed via questionnaires in which they summarised the key data on the activities under analysis, which were: the description of individual activity; the activity's dependence on scope; the activity's contribution to the value added; the number and job positions of the activity implementers; the proportion of working time spent on its implementation; the listing of the equipment used for the implementation of the activity; its depreciation in the given time period; and the statement of all costs that can be

Table 2 - Logistic costs for the production of self-adhesive laminates according to the $A B C$ model for the time period January 2009 - August 2009 (Amounts in EUR)

\begin{tabular}{|c|c|c|c|c|}
\hline Processes of logistics subsystems & $\begin{array}{l}\text { Process } \\
\text { costs }\end{array}$ & \begin{tabular}{|l|} 
Transfer of \\
costs of ID \\
processes
\end{tabular} & Total & Cost driver \\
\hline \multicolumn{5}{|c|}{ PURCHASING LOGISTICS } \\
\hline $\begin{array}{l}\text { Management and running of purchas- } \\
\text { ing logistics (scope independent - ID) }\end{array}$ & 2,991 & & & \\
\hline \multicolumn{5}{|l|}{ Scope-dependent processes of purchasing ${ }^{5}$ : } \\
\hline $\begin{array}{l}\text { 1. Operative planning and organisa- } \\
\text { tion of material assets }{ }^{6} \text { transport }\end{array}$ & 5,279 & 237 & 5,516 & $\begin{array}{l}\text { Number of trans- } \\
\text { port invoices }\end{array}$ \\
\hline $\begin{array}{l}\text { 2. Implementation of transport by own } \\
\text { means of material assets transport }\end{array}$ & 849 & 38 & 887 & Distance covered (in km) \\
\hline 3. External transport services implementation & 23,635 & 1,063 & 24,698 & Ton kilometres \\
\hline 4. Customs clearance, freight forwarding and port charges & 3,051 & 137 & 3,188 & Number of SAD \\
\hline 5. Planning of receipts and preparation of receipt claims & 2,976 & 134 & 3,110 & Number of receipt claims \\
\hline $\begin{array}{l}\text { 6. Receipt of goods including the identifica- } \\
\text { tion and control of material assets }\end{array}$ & 4,018 & 181 & 4,199 & Number of receipts \\
\hline 7. Stock warehousing, stock handling and stock control & 12,000 & 540 & 12,540 & $\begin{array}{l}\text { Average stock of raw } \\
\text { materials (in kg) }\end{array}$ \\
\hline 8. Recording of material assets flows & 4,429 & 199 & 4,628 & Number of documents \\
\hline 9. Financing of inventory of material assets & 5,387 & 242 & 5,629 & $\begin{array}{l}\text { Average stock of raw } \\
\text { materials (in kg) }\end{array}$ \\
\hline $\begin{array}{l}\text { 10. Management of complaints proce- } \\
\text { dures and return of material assets }\end{array}$ & 4,863 & 219 & 5,082 & Number of complaints \\
\hline Total purchasing logistics (1 to 10 ) & 69,478 & 2,991 & 69,478 & \\
\hline
\end{tabular}


J. Krajnc, K. Logožar, B. Korošec: Activity-Based Management of Logistic Costs in a Manufacturing Company...

\begin{tabular}{|c|c|c|c|c|}
\hline Processes of logistics subsystems & $\begin{array}{l}\text { Process } \\
\text { costs }\end{array}$ & $\begin{array}{l}\text { Transfer of } \\
\text { costs of ID } \\
\text { processes }\end{array}$ & Total & Cost driver \\
\hline \multicolumn{5}{|c|}{ INTERNAL LOGISTICS } \\
\hline Management and running of internal logistics (ID) & 442 & & & \\
\hline \multicolumn{5}{|l|}{ Scope-dependent processes of internal logistics: } \\
\hline $\begin{array}{l}\text { 11. Planning of needs for materials and } \\
\text { preparation of documents }\end{array}$ & 4,876 & 21 & 4,897 & Number of work orders \\
\hline 12. Internal transport and handling of chemicals & 534 & 2 & 536 & Chemicals used (in kg) \\
\hline 13. Internal transport and handling of paper & 20,905 & 91 & 20,996 & Paper used (in kg) \\
\hline 14. Stock warehousing, stock handling, and stock control & 9,103 & 40 & 9,143 & $\begin{array}{l}\text { Average stock of inter- } \\
\text { mediate products (in } \mathrm{m}^{2} \text { ) }\end{array}$ \\
\hline 15. Recording of material assets flows & 5,754 & 25 & 5,779 & $\begin{array}{l}\text { Number of docu- } \\
\text { ments (usage) }\end{array}$ \\
\hline 16. Financing of inventory of intermediate products & 5,884 & 26 & 5,910 & $\begin{array}{l}\text { Average stock of inter- } \\
\text { mediate products (in } \mathrm{m}^{2} \text { ) }\end{array}$ \\
\hline 17. Packing $^{7}$ & 49,947 & 218 & 50,165 & Number of palettes used \\
\hline 18. Re-reeling & 4,115 & 18 & 4,133 & $\begin{array}{l}\text { Number of work or- } \\
\text { ders for re-reeling }\end{array}$ \\
\hline Total internal logistics (11 to 18 ) & 101,560 & 442 & 101,560 & \\
\hline \multicolumn{5}{|c|}{ SALES LOGISTICS } \\
\hline Management and running of sales logistics (ID) & 4,396 & & & \\
\hline \multicolumn{5}{|l|}{ Scope-dependent processes of sales logistics: } \\
\hline 19. Delivery of finished products to the warehouse & 2,369 & 108 & 2,477 & Finished products (in $\mathrm{m}^{2}$ ) \\
\hline 20. Stock warehousing, stock handling, and stock control & 10,958 & 500 & 11,458 & $\begin{array}{l}\text { Average stock of fin- } \\
\text { ished products in } \mathrm{m}^{2}\end{array}$ \\
\hline 21. Recording of material assets flows & 3,367 & 154 & 3,521 & Number of documents \\
\hline 22. Financing of inventory of finished products & 5,387 & 246 & 5,633 & $\begin{array}{l}\text { Average stock of fin- } \\
\text { ished products in } \mathrm{m}^{2}\end{array}$ \\
\hline 23. Planning of shipping & 9,823 & 448 & 10,271 & $\begin{array}{l}\text { Number of ship- } \\
\text { ping claims }\end{array}$ \\
\hline 24. Final inspection and shipping & 7,169 & 327 & 7,496 & Number of shipments \\
\hline 25. Operative planning of transport & 2,924 & 133 & 3,057 & Number of shipments \\
\hline 26. Implementation of transport by own means of transport & 1,383 & 63 & 1,446 & Distance covered (in km) \\
\hline 27. External transport services implementation & 52,913 & 2,416 & 55,329 & Sold products in $\mathrm{m}^{2}$ \\
\hline Total sales logistics (19 to 27 ) & 100,689 & 4,396 & 100,689 & \\
\hline \multicolumn{5}{|c|}{ AFTER-SALES LOGISTICS } \\
\hline 28. Management of complaints procedures & 3,352 & & 3,352 & Number of complaints \\
\hline 29. Return of goods & 1,160 & & 1,160 & $\begin{array}{l}\text { Number of documents } \\
\text { for return of goods }\end{array}$ \\
\hline 30. Collecting and sorting of waste & 1,544 & & 1,544 & Waste in $\mathrm{kg}$ \\
\hline 31. Waste removal & 11,569 & & 11,569 & Waste in $\mathrm{kg}$ \\
\hline Total after-sales logistics (27 to 31) & 17,625 & & 17,625 & \\
\hline $\begin{array}{l}\text { TOTAL LOGISTIC COSTS for the produc- } \\
\text { tion of self-adhesive laminates }\end{array}$ & 289,352 & & 289,352 & \\
\hline Total costs of business segment "Self-adhesive laminates" & \multicolumn{3}{|c|}{$2,899,813$} & \\
\hline $\begin{array}{l}\text { Proportion of logistic costs - as \% of to- } \\
\text { tal costs of the business segment }\end{array}$ & \multicolumn{3}{|c|}{9.9783} & \\
\hline
\end{tabular}

Source: The authors' own research, based on the company's data 
Table 3 - Comparison of logistic costs and total costs per product unit calculated according to both methods for the time period January 2009 - August 2009

\begin{tabular}{|c|c|c|c|c|c|c|c|}
\hline & \multirow[b]{2}{*}{ Type of product costs } & \multicolumn{6}{|c|}{ Type of product - paper } \\
\hline & & $\begin{array}{l}\text { Un- } \\
\text { coated }\end{array}$ & $\begin{array}{l}\text { Gloss- } \\
\text { coated }\end{array}$ & Data & Thermal & $\begin{array}{l}\text { Spe- } \\
\text { cials }\end{array}$ & $\begin{array}{l}\text { Silico- } \\
\text { nized }\end{array}$ \\
\hline \multicolumn{8}{|c|}{ TOTAL LOGISTICS COSTS } \\
\hline 1. & traditional & 46,597 & 27,298 & 6,114 & 53,618 & 2,864 & 2,205 \\
\hline \multirow[t]{2}{*}{2.} & ABC model & 92,119 & 48,982 & 34,252 & 100,034 & 8,454 & 5,511 \\
\hline & $\begin{array}{l}\% \text { difference between } \mathrm{ABC} \text { and traditionally } \\
\text { disclosed logistics costs }[((2)-(1)) /(1) \times 100]\end{array}$ & $+97,7$ & $+79,4$ & $+460,2$ & $+86,6$ & $+195,2$ & $+149,9$ \\
\hline \multicolumn{8}{|c|}{ TOTAL PRODUCTION COSTS } \\
\hline 3. & traditional & 742,767 & 484,880 & 104,252 & $1,480,020$ & 40,908 & 23,020 \\
\hline 4. & ABC model & 755,681 & 485,063 & 127,748 & $1,461,322$ & 44,691 & 25,308 \\
\hline & $\begin{array}{l}\text { \% difference between all production costs, with } \\
\text { the use of } A B C \text { for logistics costs, and all tradition- } \\
\text { ally computed production costs }[((4)-(3)) /(3) \times 100]\end{array}$ & $+1,7$ & 0,0 & $+22,5$ & $-1,3$ & $+9,2$ & $+9,9$ \\
\hline
\end{tabular}

Source: The authors' own research, based on the company's data

directly allocated to the activity - as well as the type and scope of the individual activity's cost drivers in the time period under analysis.

Based on the analysis of the processes, it was possible to divide the activities of the four observed logistics subsystems into 31 scope-dependent processes (10 in purchasing, 8 in internal, 9 in sales and 4 in aftersales logistics subsystem). Thus, a total of 34 logistics processe ${ }^{4}$ were defined. Table 2 shows the established costs of these processes in the four logistics subsystems and the allocation of the scope-independent (ID) management costs of the subsystems (according to expression (1)) to their scope-dependent processes. In the far right column of the table, the measurable process effects, i.e. cost drivers for each of the defined scope-dependent processes, are specified as well.

The comparison of total logistic costs in Table 1 (EUR 138,696) and Table 2 (EUR 289,352) shows that the application of the $A B C$ model discerned or disclosed the total of $108.6 \%{ }^{9}$ more logistics costs in the production of self-adhesive laminates than was the case with the traditional approach. If we take into consideration the new total amount of costs in the analysed business segment, we realize that 'visible' logistics costs (as the proportion of total costs of the analysed business segment) increased from $4.82 \%$ to $9.98 \%$ owing to those costs which the traditional method sees as a part of indirect costs (purchasing costs, production costs, and costs of sales).

The data on the total costs of each scope-dependent logistics process were used alongside the data on the type of cost drivers and their scope in the observed period of time in order to establish the costs per unit of an individual process cost driver (according to expression (2)). To calculate the total costs of each scope-dependent logistics process for individual products, the obtained costs per unit of an individual pro- cess cost driver were multiplied (according to expression (3)) with the scope of cost drivers used for each of these products. By aggregating the logistics costs of all scope-dependent logistics processes (according to expression (4)) the total logistics costs for each of the products was calculated. They are depicted in Table 3 (seq. no. 2), which summarises the comparison of calculations of total logistics costs and of total production costs based both on the traditional method and on the proposed $A B C$ method of cost accounting.

\section{DISCUSSION}

The acquired quantitative data (see Table 2 and Table 3) exhibit a large difference (the average of 108.6\%) between the estimated logistics costs in the selected production company according to the $A B C$ model and the ones disclosed through its traditional system of cost accounting (i.e. accounting according to types of costs at the level of production programme of a group of products). These results confirm the findings of theoretical research [2], [1] concerning a potentially higher efficiency of the ABC approach to ensure the 'visibility' of logistics costs in comparison with the traditional (volume-based) cost-accounting method. If the company under analysis did not record a part of overall indirect logistics costs (i.e. costs of the cost centre 'warehousing') separately, the reported value in the 'visibility' of logistics costs of the observed business segment would be even larger. Of course, the results obtained in our study regarding the level of the estimated difference of the amount of logistics costs as disclosed under the $\mathrm{ABC}$ method compared with the traditional cost reporting method cannot be generalized to every production company. In addition, by selecting different cost drivers in the analysed company, different results would be obtained. 
Furthermore, the activity-based accounting of indirect costs ensures a more adequate allocation of these costs, which is of key importance for strategic decision making, in terms of the development of the company's activities. Since the results of our study exhibit higher overall (indirect) costs of the business segment in question compared to the costs recorded by the traditional method, it can be concluded that the extent of logistics processes in the analysed business segment is larger than the company average. Thus, the traditional method underestimated the costs of this business segment as well. So, the application of the model at the level of all groups of products in the company would show a lower-than-the-company-average extent of logistics processes and their related costs in at least one other business section of the company, provided that the amount of total indirect costs at the company level remained unchanged. However, this analysis exceeds the scope of our research.

The comparison of the costs of the researched business segment products as disclosed by both approaches (see Table 3) leads to a number of additional findings. The activity-based approach disclosed between 79.4\% (for gloss-coated papers) and 460.2\% (for data papers) more logistics costs per type of product than the traditional approach. The comparison of total costs and logistics costs shows that only the total amount of costs for gloss-coated papers remained the same regardless of the accounting method used, i.e. the same total amount of all indirect costs was allocated to this type of product according to both approaches. This finding points to the fact that the average level of the logistics processes intensity (and their related cost drivers) for this type of product equals its proportion in the costs of materials, which are used by the traditional method as the basis for the allocation of all indirect costs. Regarding other types of products (with the exception of thermal paper), the activity-based monitoring of logistics costs demonstrated that the traditional method underestimated their total costs between $1.7 \%$ (for uncoated papers) and as much as $22.5 \%$ (for data papers). A more detailed analysis of the data on cost drivers for data-paper related logistics processes showed that these types of products must be associated with the above-average purchasing logistics transport costs (as the result of frequent purchases of the required materials from abroad), as well as the above-average costs of complaints processes management (as the result of a large number of customer complaints). Only thermal papers indicate somewhat low intensity of logistics processes. That is, according to the activity-based approach of accounting logistics-related indirect costs and taking into consideration the unchanged way of allocating other indirect costs, the total costs decreased a little (by 1.3\%). An in-depth analysis of the data points to the product with high costs of materials used for the allocation of all indirect costs in the traditional approach. Concerning this particular product, the relative proportion of the external transport services used within the purchasing logistics and related packing and re-rolling activities as well as warehousing in the subsystems of purchasing and sales logistics was substantially lower than the product proportion in total direct material costs. This is why the indirect costs allocated to this product according to the traditional cost-accounting method were a bit overestimated. In the example presented in this paper, the activity-based approach of allocating indirect logistics costs to products show that the intensity of logistics processes in the analysed business segment is different from the one disclosed by the traditional approach (i.e. the allocation of costs based on the proportion of the costs of materials used) for all but one product.

The application of the ABC model as presented in this paper contributes to the existing literature dealing with the case studies of the ABC model use in the field of logistics costs. We believe that the model conceptual framework including the calculation schemes at the level of individual products and their upgrading into the system of financial reporting for management can be of value for the improvement of the accounting information system for logistics costs in other production companies.

\section{CONCLUSION}

The concept and the application of the activitybased model for logistics costs accounting in a manufacturing company presented in this paper shows that such a model can disclose far more indirect logistics costs at the level of a group of products than the traditional (volume-based) costing approach in a company. In addition, it assures more correct information regarding these costs at the level of individual products. In this way, the information on logistics costs disclosed at the level of logistics sub-systems and within those further at the level of their basic logistics processes enable a better management of these costs and, at the same time, a more efficient and more successful measurement and assessment of logistics activities effects.

The presented $A B C$ model for accounting and an improved management of logistics costs, which are mainly labelled as indirect (overhead) costs in manufacturing companies, can be adequately upgraded and utilized as a support tool for decision-making at the level of groups of customers or at the level of individual customers. With regard to the accounting of all indirect costs in a manufacturing company, the ABC approach can be improved by a detailed analysis and classification of other, non-logistic activities which may 
incur indirect costs in various kinds of manufacturing companies.

The potential for further research in the accounting of logistics costs lies primarily in supplementing the activity-based cost-accounting/management with other proactive cost management methods, particularly with target costing and benchmarking. If the model were applied on a large enough sample of companies (thus identifying a relatively large proportion of traditionally hidden logistics costs), further research into the factors influencing the levels of these costs in comparable production companies could be of great interest.

\section{REFERENCES}

1. If, for example, a company allocates total indirect costs to the products according to their direct material costs and $60 \%$ of these costs concern product $\mathrm{X}$, then $60 \%$ of all indirect costs of the company are allocated to this product as well. If the majority of the indirect costs are connected with packing and only $20 \%$ of total packing time and capacities are used for this product, then the proportion $(60 \%)$ of indirect costs allocated to product $\mathrm{X}$ and its total costs are overstated, respectively.

2. The core design of the ABC model for logistics costs accounting in a production company, which is upgraded in this paper, was developed within the postgraduate master study programme 'Accounting and Auditing' at the Faculty of Economics and Business, University of Maribor. The model is presented in detail in the master's thesis of the first author of this paper [14].

3. All basic data on costs used to test the model have been changed (i.e. multiplied) by a certain factor to protect personal data and trade secrets of the company. However, this alteration does not have any influence on the proportions of the established logistics costs.

4. A thorough research of individual logistics subsystems disclosed 15 processes which do not contribute to the value added and should be abandoned or optimised. A more detailed study exceeds the scope of this paper.

5. The costs of processes 1 to 4 also include the direct purchasing costs of material (in partial processes of external transport and fees) in the total amount of EUR 25,521. These costs are presented under number 1 in Table 1

6. Material assets concern raw materials, work in process, finished goods, and merchandise.

7. The costs of this process also include direct packaging costs (see Table 1, seq.no.2).

8. The total costs of the business segment 'Self-adhesive laminates' (see Table 2) exceed the total costs of the same segment as disclosed according to the traditional method (see Table 2) by EUR 23,966. The difference stems entirely from taking into account the level of the utilization of logistics elements and activities as well as their general costs for individual business segments. The allocation of other indirect costs to the segment is namely done in an unchanged, traditional way.

9. $(289,232-138,596) / 138,696 \times 100=108.6 \%$
JULIJANA KRAJNC, M.Sc.

E-mail: julija.krajnc@aero.si

AERO, kemična, grafična in papirna industrija, d.d.

Ipavčeva 32, 3000 Celje, Slovenija

KLAVDIJ LOGOŽAR, Ph.D.

E-mail: klavdij.logozar@uni-mb.si

BOJANA KOROŠEC. Ph. D.

E-mail: bojana.korosec@uni-mb.si

Univerza v Mariboru, Ekonomsko-poslovna fakulteta

Razlagova 20, 2000 Maribor, Slovenija

\section{POVZETEK}

\section{PROCESNI NAČIN OBVLADOVANJA STROŠKOV LOGISTIČNE DEJAVNOSTI V PROIZVODNEM PODJETJU: primer povečane vidljivosti logističnih stroškov v slovenskem podjetju za proizvodnjo papirja}

Pomemben pogoj za uspešno obvladovanje materialnih tokov in z njimi povezanih logističnih dejavnosti $v$ proizvodnih podjetjih predstavlja kar se da transparentno izkazovanje in z njihovimi povzročitelji smiselno povezano spremljanje stroškov logističnih dejavnosti. Ti so pretežno sestavina splošnih stroškov takih podjetij in pri tradicionalnem računovodenju stroškov ostajajo v veliki meri skriti oziroma ne eksplicitno vidni. Namen raziskave je oblikovanje modela procesnega spremljanja stroškov logistike v proizvodnem podjetju ter preizkus njegove učinkovitosti pri razkrivanju stroškov logistike $v$ primerjavi s tradicionalnim računovodenjem stroškov. Aplikacija modela na primeru proizvodnega podjetja dokazuje, da ta razkrije na ravni skupine proizvodov kar 108 \% več stroškov logistike kot tradicionalni model spremljanja stroškov v podjetju, z njim pridobljene razčlenjene informacije o stroških logistike pa lahko omogočajo tudi njihovo boljše obvladovanje.

\section{KLUČNE BESEDE}

logistični stroški, procesni način računovodenja stroškov, razporejanje stroškov, razvidnost stroškov, obvladovanje stroškov

\section{LITERATURE}

[1] Stapleton, D., Pati, S., Beach, E., Julmanichoti, P.: Activity-based Costing for Logistics and Marketing, Business Process Management Journal, Vol. 10, No. 5, 2004, pp. 584-597

[2] Pohlen, T.L., LaLonde, B.J.: Implementing Activitybased Costing $(A B C)$ in logistics, Journal of Business Logistics, Vol. 15., Iss. 2, 1994, pp. 1-23

[3] Wang, G., Gao, Z., Lin, T.W.: Using ABC to Improve the Logistics Value Chain in a Chinese Food Product Company, Cost Management, Vol.24, Iss. 1, 2010, pp. 3946

[4] Themido, I., Arantes, A., Fernandes, C., Guedes, A. P.: Logistic Costs Case Study -An ABC Approach, Journal of the Operational Research Society, Vol. 51, No. 10, 2000, pp. 1148-1157

[5] Cooper, R., Kaplan, R.S.: Profit Priorities from Activity-Based Costing, Harvard Business Review, Vol. 69, No.3, 1991, pp. 130-135 
[6] Hansen, D. R., Mowen, M.M.: Cornerstones of Cost Accounting, South-Western Publishing, 2009

[7] Pirttilä, T., Hautaniemi, P.: Activity-based Costing and Distribution Logistics Management, International Journal of Production Economics, Vol. 41, No. 1-3, 1995, pp. 327-333

[8] Goldsby, Th.J., Closs, D.J.: Using Activity-Based Costing to Re-engineer the Reverse Logistics Channel, International Journal of Physical Distribution \& Logistics Management, Vol. 30, No. 6, 2000, pp.500 - 514

[9] Liberatore, M.J., Miller, T. : A Framework for Integrating Activity-Based Costing and the Balanced Scorecard into the Logistics Strategy Development and Monitoring Process, Journal of Business Logistics, Vol. 19, No. 2, 1998, pp 131-154

[10] Baykasoğlu, A., Kaplanoğlu, V.: Application of ActivityBased Costing to a Land Transportation Company: A Case Study, International Journal of Production Economics, Vol. 116, No. 2, 2008, pp. 308-324

[11] Innes, J., Mitchell, F., Sinclair, D.: Activity-based Costing in the U.K.'s Largest Companies: A Comparison of 1994 Nad 1999 Survey Result," Management Accounting Research, Vol. 11,No.3, 2000, pp. 349-362
[12] Varila, M., Seppanen, M., Suomala, P.: Detailed Cost Modelling: A Case Study in Warehouse Logistics, International journal of Physical Distribution \& Logistics Management, Vol. 37, No. 3, 2007, pp. 184-200

[13] Dekker, H.C., Van Goor, A.R.: Supply Chain Management and Management Accounting: A Case Study of Activity-Based Costing," International Journal of Logistics: Research \& Applications, Vol. 3, No. 1, 2000, pp.41-52

[14] Nurminen, T., Korpunen, H., Uusitalo, J.: Applying the Activity-Based Costing to Cut-to-Length Timber Harvesting and Trucking, Silva Fennica, Vol. 43, No.5, 2009, pp. 847-870

[15] Logožar, K.: Poslovna logistika: elementi in podsistemi. GV Izobraževanje, Ljubljana, 2004

[16] Krajnc, J.: Procesni način obvladovanja stroškov logistične dejavnosti, M.Sc. thesis, University of Maribor, Faculty of Business and Economics, Maribor, 2010

[17] Koletnik, F.: Računovodstvo za notranje uporabnike informacij. Zveza računovodij, finančnikov in revizorjev Slovenije, Ljubljana, 2007

[18] Turney, P.B.: Activity-based Costing. The Performance Breakthrough, Kogan page, London, 1997 